E-ISSN: 2477-0124
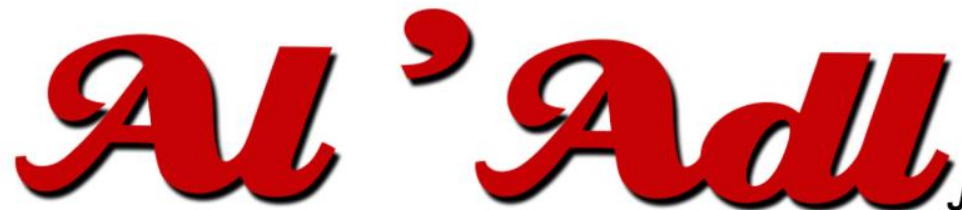

Jurnal Hukum

Editorial Office: Faculty of Law, Islamic University Of Kalimantan,

Jalan Adhyaksa No. 2 Kayutangi Banjarmasin, Kalimantan Selatan, Indonesia (70123)

Email: al_adl@uniska-bjm.ac.id

Web: http://ojs.uniska-bjm.ac.id

\section{Royalti Penggunaan Merek dalam Sistem Franchise di Indonesia menurut Hukum Islam}

\author{
Nasrullah ${ }^{1}$ \\ Fakultas Hukum Universitas Islam Kalimantan Muhammad Arsyad Al Banjari \\ Jl. Adhyaksa No.2 Kayutangi, Banjarmasin \\ Email: nasrullah_nj82@uniska-bjm.ac.id
}
Submitted
: 24 Juni 2021
Revised
Accepted
: 07 Juli 2021
: 17 Juli 2021
Published

\begin{abstract}
Business practices with the Franchise sistem in Indonesia are growing and developing, so we often encounter them around us. This kind of business sistem was basically started and popularized by westerners who incidentally is a capitalist sistem, so that for the Indonesian people, who are predominantly Muslim, this franchise is certainly a business sistem that must be studied in depth according to sharia, because specifically the use of brands must be charged other than fees other. This research is a normative juridical research with library research method. Sources of legal materials in this study include primary legal materials, namely regulations on Franchise, secondary legal materials, namely references in the form of literature related to the Franchise business, then tertiary legal materials such as Indonesian language dictionaries. From the research, it is known that the Franchise sistem applied in Indonesia is a business format franchise sistem, where a Franchisee obtains the right to market and sell products or services in a specific area or location using the operational and marketing standards of the Franchisor. The law of fee royalty for the use of brands in the franchise business sistem follows the law of syirkah which is allowed as long as the business, product or service is not prohibited by Islamic law.
\end{abstract}

Keywords : Bussines; Franchise; Islamic Law.

\title{
Abstrak
}

Praktik bisnis dengan menggunakan sistem Franchise di Indonesia semakin tumbuh dan berkembang sehingga tidak jarang kita temui di sekitar kita. Sistem bisnis seperti ini pada dasarnya dimulai dan dipopulerkan oleh orang barat yang notabenenya adalah sistem kapitalis, sehingga bagi masyarakat Indonesia yang mayoritas muslim tentu Franchise ini merupakan sistem bisnis yang harus dikaji secara mendalam secara syara' karena khusus penggunaan merek harus dikenakan biaya selain biaya-biaya yang lainnya. Penelitian ini merupakan penelitian yuridis normatif dengan metode penelitian library research (kajian kepustakaan). Sumber bahan hukum dalam penelitian ini meliputi bahan hukum primer yaitu regulasi-regulasi tentang waralaba, bahan hukum sekunder yaitu referensi yang berupa literatur-literatur terkait dengan bisnis Franchise, kemudian bahan hukum tersier seperti kamus bahasa Indonesia. Dari penelitian diketahui bahwa sistem Franchise yang diterapkan di Indonesia adalah sistem franchise format bisnis, dimana seorang Franchisee memperoleh hak untuk memasarkan dan menjual produk atau pelayanan dalam suatu wilayah atau lokasi yang spesifik dengan menggunakan standar operasional dan pemasaran dari Franchisor. Adapun hukum fee royalti penggunaan merek dalam sistem bisnis

\footnotetext{
${ }^{1}$ Tenaga Pengajar Prodi Ilmu Hukum Fakultas Hukum Uniska MAB Banjarmasin.
} 
Franchise mengikut pada hukum syirkah atau musyarakah yaitu diperbolehkan sepanjang usaha, produk ataupun jasanya tidak dilarang oleh syari'at Islam.

Kata Kunci : Bisnis; Waralaba; Hukum Islam.

\section{PENDAHULUAN}

Perkembangan ekonomi akibat dari globalisasi ekonomi adalah meningkatnya kebutuhan perusahaan-perusahaan terhadap modal dan kebutuhan menuntut struktur permodalan yang kompleks yang pada gilirnnya berimplikasi pada berkembangnya berbagai macam sistem transaksi dan bisnis dengan penyertaan modal secara informal, salah satunya adalah bisnis Franchise atau waralaba. Menurut Amir Karamoy ${ }^{2}$, bahwa Franchise adalah suatu pola kemitraan usaha antara perusahaan yang memiliki merek dagang dikenal dan sistem manajemen, keuangan dan pemasaran yang telah mantap, disebut Franchisor, dengan perusahaan atau individu yang memanfaatkan atau menggunakan merek dan sistem milik Franchisor, disebut Franchisee. Secara umum Franchise merupakan suatu pengaturan bisnis dimana sebuah perusahaan (franchisor) memberi hak pada pihak independen (franchisee) untuk menjual produk atau jasa perusahaan tersebut dengan peraturan yang ditetapkan oleh franchisor. Franchisee menggunakan nama, goodwill, produk dan jasa, prosedur pemasaran, keahlian, sistem prosedur operasional, dan fasilitas penunjang dari perusahaan franchisor. ${ }^{3}$

Adapun konsep Franchise di Indonesia juga telah diatur dalam Peraturan Menteri Perdagangan Nomor: 12/M-DAG/PER/3/2006, di mana regulasi ini memberikan definisi Franchise yang dikenal dengan nama waralaba tersebut sebagai adalah perikatan antara pemberi waralaba dengan penerima waralaba dimana penerima waralaba diberikan hak waralaba untuk menjalankan usaha dengan memanfaatkan dan/atau menggunakan hak kekayaan intelektual atau penemuan atau ciri khas usaha yang dimiliki pemberi waralaba dengan suatu imbalan berdasarkan persyaratan yang ditetapkan oleh pemberi waralaba dengan sejumlah kewajiban menyediakan dukungan konsultasi operasional yang berkesinambungan oleh pemberi waralaba kepada penerima waralaba."

Melalui sistem Franchise ini, peluang pendapatan yang sangat besar datang untuk mengembangkan sejumlah besar outlet Frachisee bagi Franchisor dan Franchisee dengan nilai bulanan yang besar ini tidak hanya mencakup biaya operasi Franchisor pemilik untuk

\footnotetext{
${ }^{2}$ Amir Karamoy, (2013), Percaturan Waralaba Indonesia, Jakarta: PT Foresight Asia, hlm. 13.

${ }^{3}$ Sri Hudiarini, dkk. (2018), "Waralaba Model Bisnis Baru yang Berkelanjutan Ditinjau dari Aspek Hukum", Jurnal Panorama Hukum, Volume 3 Nomor 1 Juni 2018 ISSN : 2527-6654, hlm. 59.
} 
mendukung pemilik Franchisor. ${ }^{4}$ Bisnis Franchise diperkenalkan pertama kali oleh Isaac Singer seorang pencipta mesin jahit merek Singer pada tahun 1851 di Amerika Serikat. Pelopor bisnis Franchise terkenal di Amerika Serikat antara lain adalah ${ }^{5}$ :

1. The Coca-Cola Corporation di bidang minuman

2. Mc Donald's Corporation di bidang makanan

3. General Motor Corporation di bidang otomotif

4. Hilton Hotel di bidang perhotelan

5. Computer Centre Inc. di bidang computer

6. Jony King di bidang pelayanan kebersihan

Sistem bisnis Franchise sangat diminati oleh pebisnis asing dimana mereka memberikan izin kepada pengusaha lokal untuk mengelola Franchise asing tersebut dan tentunya akan berakibat menimbulkan saingan yang berat bagi pengusaha kecil lokal yang bergerak di bidang usaha sejenis. Fakta sistem franchise terlihat bahwa pada umumnya konsumen cenderung datang untuk membeli produk atau jasa dikarenakan reputasi brandname dari franchise itu sendiri, ${ }^{6}$ sehingga kepopuleran brandname suatu franchise juga merupakan hal yang sangat menentukan dalam pertumbuhan sistem bisnis ini. Begitu menguntungkannya bisnis Franchise ini, maka pemerintah berkepentingan pula untuk mengembangkan bisnis di Indonesia guna terciptanya iklim kemitraan usaha melalui pemanfaatan lisensi sistem bisnis Franchise. Melalui sistem bisnis Franchise ini, kegiatan usaha para pengusaha kecil di Indonesia dapat berkembang secara wajar dengan menggunakan resep, teknologi, kemasan, manajemen pelayanan, merek dagang / jasa pihak lain dengan membayar sejumlah royalti berdasarkan lisensi Franchise.

Dalam kerjasama sistem Franchise, pengembangan sumber daya manusia berkualitas menjadi penting melalui pelatihan keterampilan menjalankan usaha waralaba yang diselenggarakan oleh pihak pemberi lisensi Franchise. Para pengusaha kecil tidak perlu bersusah payah menciptakan sendiri sistem bisnis, sudah cukup dengan menyediakan modal kemitraan usaha, membayar royalti, dengan memanfaatkan sistem bisnis Franchise asing melalui lisensi bisnis. Mengingat bahwa konsep bisnis dengan sistem Franchise yang

\footnotetext{
${ }^{4}$ Dede Sulaeman, (2019), "Keuntungan yang Didapat dari Mengembangkan Usaha dengan Sistem Franchise (Studi Kasus di Indonesia)", Jurnal JDM, Volume 2, Nomor 01 April 2019, hlm. 7.

${ }^{5}$ Abdulkadir Muhammad, (2004), Hukum Perusahaan Indonesia, Bandung: Citra Aditya Bakti, hlm. 335.

${ }^{6}$ Eko Wibowo, (2007),"Faktor-faktor yang Mempengaruhi Pertumbuhan Jaringan Waralaba (Studi Kasus pada Yayasan Soroban Mental Aritmatika Indonesia Semarang)", Jurnal Sains Pemasaran Indonesia, Volume VI, Nomor 1, Mei 2007, hlm. 304.
} 
diterapkan di Indonesia ini dibentuk dan disebarluaskan oleh kalangan kapitalis, sedangkan masyarakat Indonseia mayoritas penduduknya beragama Islam tentu konsep franchise ini tidak serta merta mendapat penerimaan dari semua kalangan. Terkait hal tersebut, kalau kita perhatikan aturan jual beli dalam hukum Islam, maka tidak akan terdapat ketentuan mengenai pembayaran secara periodik atau royalty fee terhadap produk yang dijual sebagaimana yang diterapkan dalam sistem bisnis Franchise ini. Selain itu, apabila ditinjau dari definisi franchis, dalam hal ini waralaba, dalam peraturan perundang-undangan terutama aturan teknisnya yang salah satunya adalah Keputusan Menteri Perindustrian dan Perdagangan Republik Indonesia No.259/MPP/KEP/7/1977 tentang Ketentuan dan Tata Cara Pelaksanaan Pendaftaran Waralaba tidak ditegaskan adanya fee ataupun royalty fee dalam sistem bisnis ini.

Berdasarkan hal tersebut, maka permasalahan ini menurut penulis perlu diteliti dan dikaji secara lebih mendalam dan lebih komprehensif, terutama adanya pembayaran royalty fee terhadap merek dagang di luar pembayaran terhadap bahan-bahan dagangan yang akan diperjualbelikan oleh Franchisee.

\section{RUMUSAN MASALAH}

Penelitian ini disusun berdasarkan rumusan masalah, yaitu:

1. Bagaimana sistem bisnis Franchise yang diterapkan di Indonesia?

2. Bagaimana pandangan hukum Islam terhadap royalti penggunaan merek dalam sistem Franchise yang diterapkan di Indonesia?

\section{METODE PENELITIAN}

Penelitian ini adalah penelitian yuridis normatif dimana metode penelitian ini dilakukan dengan cara sistematis, penelitian jenis ini disebut juga dengan "legal research" atau "legal research instruction". ${ }^{7}$ Penelitian ini menggunakan bahan hukum yang bersifat autoratatif, di antaranya yaitu: Undang-Undang Nomor 15 Tahun 2001 tentang Merek, Peraturan Pemerintah RI Nomor 42 Tahun 2007 tentang Waralaba, dan Peraturan Menteri Perdagangan Republik Indonesia Nomor: 12/M-DAG/PER/3/2006 tentang Penyelenggaraan Waralaba

Teknik pengumpulan bahan hukum dilakukan dengan cara melakukan inventarisasi dan identifikasi terhadap bahan hokum baik itu sejumlah peraturan perundang-undangan, literatur

\footnotetext{
${ }^{7}$ Soerjono Soekanto dan Sri Mamudji, (2006), Penelitian Hukum Normatif Tinjauan Singkat, Jakarta: Rajawali Pers, hlm. 23.
} 
maupun referensi lainnya yang berkaitan dengan pembahasan dalam penelitian ini. Adapun teknik analisis yang digunakan adalah content analysis yang merupakan metode analisis integratif dan secara konseptual diarahkan untuk menemukan, mengidentifikasi, mengolah dan menganalisis bahan hukum untuk memahami makna, signifikansi dan relevansinya. ${ }^{8}$ Metode analisa data adalah analisis normatif, yaitu menginterpretasikan bahan hukum berdasarkan pada norma, teori-teori dan doktrin hukum yang berkaitan dengan pokok permasalahan yang kemudian ditinjau dari hukum Islam.

\section{PEMBAHASAN}

\section{Sistem Bisnis Franchise di Indonesia}

Kata Franchise berasal dari bahasa Prancis kuno yang berarti "kejujuran atau kebebasan", 9 yang berarti memberi kebebasan kepada para pihak. Pengertian Franchise menurut United Nations Centre on Transnational Corporation (UNCTC), yaitu: "Franchise is particular from licensing agreement implying a constinuing relationship in which the Franchisor provide rights usually including the use trademark or brand name plus services of technical assistance, training, merchandising and management in return for certain place". 10 Dari definisi ini dapat dipahami bahwa Franchise merupakan persetujuan lisensi dari suatu hubungan yang berkesinambungan, yang mana Franchisor menyediakan hak-hak khususnya yang di dalamnya termasuk penggunaan merek atau nama ditambah dengan pelayanan asisten teknik, pelatihan, peralatan dan manajemen serta penyediaan tempat selain itu, perjanjian Franchise melibatkan dua pihak yakni pihak pemilik usaha (Franchisor) dan penyewa atau pihak yang mendapat izin usaha (Franchise).

Di Indonesia sendiri, Franchise dikenal "waralaba", wara artinya lebih, dan laba berarti untung, jadi waralaba berarti lebih untung. ${ }^{11}$ Adapun Franchise menurut Pasal 1 Peraturan Pemerintah Nomor 42 Tahun 2007 tentang Waralaba, menyebutkan bahwa: "Waralaba adalah hak khusus yang dimiliki oleh orang perseorangan atau badan usaha terhadap sistem bisnis dengan ciri khas usaha dalam rangka memasarkan barang dan/atau jasa yang telah terbukti berhasil dan dapat dimanfaatkan dan/atau digunakan oleh pihak lain

\footnotetext{
${ }^{8}$ Burhan Bunging, (2007), Metodologi penelitian kualitatif: Aktualisasi Metodologi ke Arah Ragam Varian Kontemporer, Jakarta: PT. Raja Grafindo Persada, hlm. 203.

${ }^{9}$ Walid Darmawan, (2010), "Analisis Sistem Penetapan Franchise Fee dan Royalty Fee Pada Franchise BRC”, Jurnal Al-Iqtishad: Volume II, Nomor 1, Januari 2010, hlm. 38.

${ }^{10}$ UNCTC, (1987), Transnational Corporation and Technology Transfer: Effects and Policy Issues, United Nations, New York: UNCTC, hlm. 4.

${ }^{11}$ Walid Darmawan, Op.cit., hlm. 39.
} 
berdasarkan perjanjian waralaba." Henry Campbell Black sebagaimana yang dikutip oleh Juajir Sumardi, memberikan beberapa pengertian mengenai Franchise, sebagai berikut: ${ }^{12}$

a. Franchise is a special privilege to do certain things conferred by government on individual $v$ corporation, and which does not belong citizens generally of common right; e.g, right granted to offer cable television service.

b. Franchise is a privilige or sold, such as to use a name or to sell product or service. The right given by a manufacturer or supplier to a retailer to use his products and name on terms and conditions mutually agreed upon.

c. Franchise is a lincense from owner of a trade mark or trade name permitting another to sell a product or service under that name or mark.

Berdasarkan dalam terjemahan bebas pendapat di atas, Franchise dapat dipahami dalam 3 (tiga) definisi. Pertama, sebagai hak khusus yang istimewa untuk melakukan sesuatu yang diberikan oleh Pemerintah terhadap individu atau perusahaan, yang bukan merupakan hak warga negara pada umumnya; misalnya hak untuk menawarkan layanan televisi kabel. Kedua, sebagai hak istimewa atau menjual, seperti untuk menggunakan nama atau menjual barang atau jasa. Ketiga, sebagai pemberian lisensi dari pemilik merek dagang atau nama dagang yang mengizinkan pihak lain untuk menjual barang atau jasa dibawah nama dan merek tersebut. Secara lebih mendalam, Salim HS mendefinisikan Franchise sebagai suatu kontrak yang dibuat antara Franchisor dan Franchisee, dengan ketentuan pihak Franchisor memberikan lisensi kepada Franchisee untuk menggunakan merek barang atau jasa dalam jangka waktu tertentu dan pembayaran sejumlah royalti tertentu kepada Franchisor. ${ }^{13}$ Hal tersebut kemudian Gunawan Widjaja menekankan bahwa Franchise menekankan pada penggunaan sistem, metode, tata cara, prosedur, metode pemasaran dan penjualan maupun hal-hal lain yang telah ditentukan oleh Franchisor secara eksklusif dan tidak boleh dilanggar atau diabaikan oleh penerima lisensi. ${ }^{14}$

Adapun perjanjian lisensi itu sendiri menurut Undang-Undang Nomor 15 Tahun 2001 tentang Merek yaitu izin yang diberikan oleh pemilik merek terdaftar kepada pihak lain melalui suatu perjanjian berdasarkan pada pemberian hak (bukan pengalihan hak) untuk menggunakan Merek tersebut, baik untuk seluruh atau sebagaian jenis barang dan/atau jasa

\footnotetext{
${ }^{12}$ Juajir Sumardi, (1995), Aspek-aspek hukum perusahaan tradisional dan Franchise, Bandung: Citra Aditya Bakti, hlm. 13.

${ }^{13}$ Salim HS., (2008), Perkembangan Hukum Kontrak Innominat di Indonesia, Jakarta: Sinar Grafika, hlm. 163.

${ }^{14}$ Gunawan Widjaja, (2003), Waralaba, Jakarta: PT. Raja Grafindo Persada, hlm. 12.
} 
yang didaftarkan dalam jangka waktu dan syarat tertentu. ${ }^{15}$ Menurut Adrian Sutendi, perjanjian lisensi meliputi satu bidang kegiatan saja, misalnya pemberian izin lisensi bagi penggunaan merek tertentu ataupun lisensi pembuatan satu/beberapa jenis barang tertentu sedangkan pada perjanjian waralaba, pemberian lisensi melibatkan berbagai macam hak milik intelektual, seperti nama perniagaan, merek, model, desain."

Pada prinsipnya, Franchise dapat dilihat dari 2 (dua) aspek yaitu aspek yuridis dan aspek bisnis. Dari aspek yuridis, Franchise dapat diartikan sebagai: "Perikatan di mana salah satu pihak diberikan hak untuk memanfaatkan dan/atau menggunakan hak atas kekayaan intelektual atau penemuan atau ciri khas yang dimiliki pihak lain dengan suatu imbalan berdasarkan persyaratan dan penjualan barang dan/atau jasa.". ${ }^{17}$ Selain itu, rumusan dari Pasal 1 Keputusan Menteri Perindustrian dan Perdagangan Republik Indonesia No.259/MPP/KEP/7/1977 tentang Ketentuan dan Tata Cara Pelaksanaan Pendaftaran Waralaba menyebutkan bahwa:

"Pemberi waralaba, yaitu badan usaha atau perorangan yang memberikan haknya kepada pihak lain untuk memanfaatkan dan/atau menggunakan hak atas kekayaan intelektual atau penemuan atau ciri khas usaha yang dimiliki oleh pemberi waralaba, sedangkan penerima waralaba adalah badan usaha atau perorangan yang diberikan hak untuk memanfaatkan dan/atau menggunakan hak atas kekayaan intelektual atau penemuan atau ciri khas usaha yang dimiliki pemberi waralaba." 18

Adapun dari aspek bisnis, menurut Bryce Webster yangdikutip oleh Ridhwan Khaerandy, Franchise adalah "Salah satu metode produksi dan pendistribusian barang dan jasa kepada konsumen dengan suatu standar dan sistem eksploitasi tertentu. Pengertian standar dan eksploitasi tersebut meliputi kesamaan dan penggunaan nama perusahaan, merek, sistem produksi, tata cara pengemasan, penyajian dan pengedarannya." ${ }^{19}$ Secara ringkas, Franchise merupakan perjanjian mengenai metode pendistribusian barang dan jasa kepada konsumen. Franchisor memberikan bantuan kepada Franchisee dan sebagai imbalannya Franchise diharuskan membayar sejumlah uang kepada Franchisor dalam bentuk innitial fee dan royalty, ${ }^{20}$ dan hal yang harus diperhatikan bahwa Franchisee tersebut berjalan di bawah peraturan merek dagang, bentuk dan prosedur dari Franchisor, dan Franchisee telah

\footnotetext{
${ }^{15}$ Undang-Undang Nomor 15 Tahun 2001 tentang Merek.

${ }^{16}$ Adrian Sutendi, (2008), Hukum Waralaba, Bogor: Ghalia Indonesia, hlm. 93.

${ }^{17}$ Peraturan Pemerintah Nomor 42 Tahun 2007 tentang Waralaba, Pasal 1 Angka 1.

${ }^{18}$ Keputusan Menteri Perindustrian dan Perdagangan Nomor 259/MPP/KEP/7/1977 tentang Ketentuan dan Tata Cara Pelaksanaan Pendaftaran Waralaba, hlm. 2.

${ }^{19}$ Ridhwan Khaerandy, (1992), Aspek-Aspek Hukum Franchise, Yogyakarta: Majalah UNISA, hlm. 87.

${ }^{20}$ Suharnoko, Loc.cit.
} 
atau akan membuat sebuah penanaman modal yang penting pada bisnisnya sebagai sumber pendapatannya. $^{21}$

Berdasarkan berbagai definisi mengenai Franchise di atas, terdapat beberapa unsur dalam sistem kerjasama bisnis tersebut, yatiu:

1. Adanya perikatan;

2. Adanya hak pemanfaatan dan/atau penggunaan atas sebuah perusahaan, merek, sistem produksi, tata cara pengemasan, penyajian dan pengedarannya;

3. Adanya subyek, yakni pihak Franchisor (pemberi waralaba) dan pihak Franchise (penerima waralaba);

4. Adanya obyek, yakni hak atas kekayaan intelektual, penemuan baru maupun ciri khas usaha;

5. Adanya imbalan, jasa atau sejumlah fee yang harus dibayarkan oleh pihak Franchise kepada pihak Franchisor; dan

6. Adanya persyaratan dan penjualan barang.

Bisnis Franchise juga dicirikan dengan adanya:

1. Franchisor yang menawarkan paket usaha;

2. Franchisee yang memiliki unit usaha (outlet) yang memanfaatkan paket usaha milik Franchisor;

3. Ada kerjasama antara Franchisor dan Franchisee dalam hal pengelolaan unit usaha; dan

4. Ada kontak tertulis yang mengatur kerjasama.

Kemudian dalam Pasal 5 Peraturan Pemerintah Republik Indonesia Nomor 42 Tahun 2007 tentang Waralaba menyatakan bahwa kontrak bisnis franchise paling tidak mencantumkan hak dan kewajiban para pihak. Dalam implementasinya, hak dan kewajiban para pihak tersebut dituliskan dalam sebuah perjanjian. ${ }^{22}$ Namun yang jelas, pada dasarnya kontrak Franchise berada diantara kontrak lisensi dan distributor. Adanya pemberian izin oleh pemegang Hak Milik Intelektual atau know-how lainnya kepada pihak lain untuk menggunakan merek atau prosedur tertentu merupakan unsur perjanjian lisensi. ${ }^{23}$

Dari uraian di atas, maka inti dari bisnis Franchise ini adalah perjanjian lisensi. Para pihak yang akan menyelenggarakan usaha franchise ini harus berdasarkan perjanjian tertulis

\footnotetext{
${ }^{21}$ Martin Mendelsohn, (1986), The Guide to Franchising, England: Oxford, hlm. 6.

${ }^{22}$ Putu Eka Trisna Dewi, (2015), "Implementasi Ketentuan Restrukturisasi Kredit terhadap Debitur Wanprestasi pada Kredit Perbankan”, Jurnal Magister Hukum Udayana, Volume 4, Nomor 2, hlm. 245.

${ }^{23}$ Sri Redjeki Slamet, (2015), "Waralaba (Franchise) di Indonesia”, Jurnal Lex Jurnalica, Volume 8 Nomor 2, April 2011, hlm. 131.
} 
yang dibuat antara pihak Franchisor dan Franchisee. ${ }^{24}$ Perjanjian lisensi dalam sistem Franchise tersebut diikuti oleh kewenangan pemilik merek untuk melakukan kontrol guna menjamin kualitas barang dan jasa yang dilisensikan dan juga punya kewenangan baik seluruhnya maupun sebahagian kontrol atas bisnis yang bersangkutan yang tidak berkaitan dengan persyaratan kualitas yang telah disebutkan. ${ }^{25}$ Apabila kita tinjau dari perjanjian lisensinya, Franchisee wajib membayar sejumlah royalti untuk imbalan atas merek dan sistem yang dibeli berdasarkan kesepakatan dalam perjanjian waralaba tersebut. Selain membayar royalti, Franchisee juga dikenakan kewajiban yang telah ditetapkan oleh franchisor untuk mendesain perusahaannya sedemikian rupa sehingga menyerupai dengan desain Franchisor. ${ }^{26}$ Satu hal lagi yang patut dikemukakan untuk membedakan Franchise dengan lisensi adalah Franchise lebih menyangkut bidang perdagangan retail dan jasa yang merupakan perdagangan langsung dengan pemakaian barang dan jasa tersebut. Kesimpulannya, Franchise merupakan salah satu bagian dari lisensi.

Adapun subyek dan obyek hukum dari sistem Franchise sehingga terbentuknya sebuah perikatan Franchise, sebagai berikut:

1. Subyek Franchise

Menurut Peraturan Pemerintah RI Nomor 16 Tahun 1997 tentang Waralaba, Subyek hukum Franchise terdiri dari 2 (dua) yaitu:

a. Franchisor, yaitu orang atau badan usaha yang memberikan lisensi, baik berupa paten, penggunaan merek perdagangan / merek jasa, ciri khas maupun hal-hal pendukung lainnya kepada Franchise.

b. Franchise, yaitu orang atau badan usaha yang menerima lisensi dari Franchisor untuk dapat menggunakan merek perdagangan / merek jasa maupun ciri khas dari Franchisor, namun harus tetap tunduk kepada peraturan dan tata cara dari Franchisor.

Namun, selain 2 (dua) subyek hukum tersebut masih terdapat dua pihak lainnya yang dapat dikaitkan sebagai subyek hukum Franchise dalam perjanjian Franchise yang juga terkena dampak dari perjanjian ini, yakni :

a. Franchise lain dalam sebuah sistem Franchise (franchising sistem) yang sama; dan

\footnotetext{
${ }^{24}$ Bella Katrinasari, (2017), "Tinjauan Hukum Terhadap Wanprestasi Royalty Rahasia Dagang Dalam Perjanjian Waralaba", Privat Law, Volume V, Nomor 1 Januari-Juni 2017, hlm. 86

${ }^{25}$ Moch Basarah dan H.M. Faiz Mufidin, (2008), Bisnis Franchise dan Aspek-Aspek Hukumnya, Bandung: PT. Citra Aditya Bakti, hlm. 36.

${ }^{26}$ Made Martarina Kusumayanti, dkk. "Implementasi Perlindungan Hukum bagi Franchisor dalam Perjanjian Waralaba (Pada Edam Burger di Denpasar)", Artikel, Fakultas Hukum Universitas Udayana, hlm. 5-6. Sumber: https://ojs.unud.ac.id/index.php/kerthasemaya/article/view/43775, diakses tanggal 20 Juni 2020.
} 
b. Konsumen atau klien dari Franchise maupun masyarakat sebagai pengguna produk dan jasa pada umumnya.

\section{Obyek Franchise}

Obyek dalam Franchise adalah lisensi. Lisensi adalah izin yang diberikan oleh Franchisor kepada Franchise dalam rangka mendistribusikan produknya ke wilayah lain.

Ada dua kriteria lisensi sebagaimana yang telah dikemukakan oleh Dieter Plaff, yaitu :

a. Lisensi dengan tujuan ekonomis, yaitu jenis lisensi yang bertujuan untuk mencapai suatu hasil penjualan tertentu yang biasanya bersifat komersil; dan

b. Lisensi secara yuridis, yaitu instrumen hukum yang digunakan untuk mencapai tujuan ekonomis tersebut.

Berdasarkan kriteria-kriteria yang telah dikemukakan oleh Dieter Plaff, maka lisensi dapat dibagi menjadi tiga macam, yaitu sebagai berikut:

a. License exchange contract, yaitu perjanjian antara para pesaing yang bergerak dalam kegiatan yang sama atau memiliki hubungan yang erat, sehingga disebabkan masalahmasalah teknis, mereka tidak dapat melakukan kegiatan tanpa adanya pelanggaran hakhak termasuk hak milik perindustrian dari pihak lain. Oleh karena itu, dalam License exchange contract, mereka sepakat untuk menyampingkan hak masing-masing untuk mengadakan penuntutan terhadap perbuatan yang merupakan pelanggaran di bidang hak milik perindustrian tersebut. Di sini, lisensi yang diberikan lebih dititikberatkan pada pemberian izin atau pembayaran royalti.

b. License Return Contract, yaitu kebalikan dari jenis lisensi yang pertama, dalam kelompok ini perjanjian itu dari luarnya saja akan tampak sebagai perjanjian lisensi, namun sebenarnya bukan perjanjian lisensi dalam arti sebenarnya. Hal tersebut dikarenakan perjanjian yang dibuat hanya dengan tujuan untuk penyelundupan pajak, dengan cara seolah-olah suatu cabang perusahaan di suatu negara tertentu membayar royalti kepada perusahaan induknya di negara lain.

c. License in the right meaning of contract, yaitu lisensi dalam arti yang sebenarnya, tanpa adanya masalah-masalah yang terdapat dalam lisensi jenis lainnya. Lisensi jenis ini terdapat adanya perikatan antara Franchisor dan Franchise secara yuridis, sehingga perikatan yang dilakukan akan menguntungkan kedua belah pihak, tanpa adanya unsur penipuan maupun unsur-unsur lain yang tidak benar.

Sebagai suatu perjanjian, Franchise mempunyai subyek dan obyek hukum di mana subyek hukum Franchise adalah pemberi waralaba dan penerima waralaba. Pengertian dari 
Pemberi waralaba dan penerima waralaba diatur dalam Pasal PP No. 42 Tahun 2007 Pasal 3 dan Pasal 4, yang berbunyi:

1. Pasal 3: "Pemberi Waralaba adalah orang perseorangan atau badan usaha yan memberikan hak untuk memanfaatkan dan/atau menggunakan Waralaba yang dimilikinya kepada Penerima Waralaba."

2. Pasal 4: "Penerima Waralaba adalah orang perseorangan atau badan usaha yang diberikan hak oleh Pemberi Waralaba untuk memanfaatkan dan/atau menggunakan Waralaba yang dimiliki Pemberi Waralaba."

Adapun penerima waralaba menurut Kepmendag No. 12/MDAG/Per/3/2006 Pasal 4 dan 5 dibagi menjadi dua yakni:

1. Pasal 4: "Penerima Waralaba Utama (Master Franchisee) adalah Penerima Waralaba yang melaksanakan hak membuat Perjanjian Waralaba Lanjutan yang diperoleh dari Pemberi Waralaba dan berbentuk Perusahaan Nasional."

2. Pasal 5: "Penerima Waralaba Lanjutan adalah badan usaha atau perorangan yang menerima hak untuk memanfaatkan dan/atau menggunakan hak kekayaan intelektual atau penemuan atau ciri khas usaha yang dimiliki Pemberi Waralaba melalui Penerima Waralaba Utama."

Obyek hukum dalam perjanjian Franchise atau klausula-klausula perjanjian itu sendiri sendiri menurut PP No. 42 Tahun 2007 Pasal 5 bahwa perjanjian Franchise memuat klausula paling sedikit:

1. Nama dan alamat para pihak;

2. Jenis Hak Kekayaan Intelektual;

3. Kegiatan usaha;

4. Hak dan kewajiban para pihak;

5. Bantuan, fasilitas, bimbingan operasional, pelatihan, dan pemasaran yang diberikan Pemberi Waralaba kepada Penerima Waralaba;

6. Wilayah usaha;

7. Jangka waktu perjanjian;

8. Tata cara pembayaran imbalan;

9. Kepemilikan, perubahan kepemilikan, dan hak ahli waris;

10. Penyelesaian sengketa; dan

11. Tata cara perpanjangan, pengakhiran, dan pemutusan perjanjian. 
Meminjam pendapat Bryce Webster, bentuk Franchise terdiri dari 3 (tiga) macam, yaitu: ${ }^{27}$

1. Product franchising, yaitu Franchise yang Franchisornya memberikan lisensi kepada Franchise untuk menjual barang hasil produksinya, sedangkan Franchise hanya berfungsi sebagai distributor dari produk Franchisor. Sering kali terjadi Franchise diberi hak eksklusif untuk memasarkan produk tersebut di suatu wilayah tertentu.

2. Manufacturing Franchises, yaitu suatu Franchise di mana Franchisor memberikan resep atau rahasia dari suatu proses produksi. Franchise memasarkan barang-barang itu dengan standar produksi dan merek yang sama dengan yang dimiliki oleh Franchisor. Bentuk Franchise semacam ini banyak digunakan dalam produksi dan distribusi minuman soft drink.

3. Business format franchising, yaitu suatu Franchise yang Franchisenya mengoperasikan suatu kegiatan bisnis dengan memakai nama Franchisor. Franchise tetap diakui sebagai anggota kelompok yang berusaha dalam bisnis ini dan sebagai imbalan dari penggunaan nama Franchisor, maka Franchise harus mengikuti metode-metode standar pengoperasian dan berada di bawah pengawasan Franchisor dalam hal bahan-bahan yang digunakan, pilihan tempat usaha, desain tempat usaha, jam penjualan, persyaratan karyawan.

Namun menurut Stephen Fox penggolongan Franchise hanya 2 jenis, yaitu: ${ }^{28}$

1. Franchise produk, yaitu Franchise jenis ini diidentifikasikan dengan produk atau nama dagang Franchisor. Dalam Franchise jenis ini Franchisor adalah pembuat produk. Franchise jenis ini merumuskan ketentuan bahwa pihak Franchisor selain mendapatkan biaya penyewaan merek dagang juga mendapatkan pembagian dari hasil penjualan produk sesuai dengan ketentuan dalam kontrak Franchise. Misalnya: Franchise otomotif dan minuman ringan.

2. Franchise format bisnis, yaitu menjalankan penjualan barang dan jasa berdasarkan kepada sistem penjualan yang dirancang oleh Franchisor. Franchise jenis ini memungkinkan Franchisor hanya mendapatkan keuntungan dari uang royalti yang biasanya berlanjut atas penggunaan nama/merek dagang beserta sistem bisnisnya. ${ }^{29}$

Pada Franchise format bisnis, pihak penyewa menjalankan penjualan barang atau jasa berdasarkan sistem penjualan yang dirancang oleh Franchisor. Pada umumnya, pada

\footnotetext{
${ }^{27}$ Bryce Webster, (1986), The Insider's Guide to Franchising, AMACON, hlm. 6.

${ }^{28}$ Stephen Fox, (1993), Membeli dan Menjual Bisnis dan Franchise, Jakarta: Elex Media Konputindo, hlm. 45 .

${ }^{29}$ Ibid., hlm. 218.
} 
Franchise jenis ini pihak Franchisor bukanlah pembuat produk walaupun mungkin Franchisor membuat satu atau beberapa komponen dari produk yang dijual penyewa. Pada Franchise jenis ini, Franchisor selain menerima biaya Franchise, juga akan menerima uang melalui royalti dan berlanjut atas penggunaan nama atau merek dagang beserta sistem bisnisnya yang dijalankan oleh pihak penyewa. Sekarang Franchise jenis ini banyak dijadikan sebagai pilihan oleh para Franchisor di Indonesia. Dalam Franchise format, pihak Franchisor memberikan lisensi kepada penyewa untuk membuka toko eceran, store atau jaringan penjualan atas berbagai produk dan pelayanan di bawah nama Franchisor. Business Format Franchisee merupakan kegiatan-kegiatan bisnis eceran yang paling nyata untuk memahami pengertian Franchise. Di sini pihak Franchisor memberikan lisensi atas metode-metode yang telah ditetapkan dan diidentifikasi dengan merek dagangnya. Metode-metode yang dioperasikan oleh penyewa harus sesuai dan di bawah pengawasan Franchisor. Sering juga pihak Franchisor melengkapi bantuan bagi pengoperasian bisnis Franchise.

Menurut Juajir Sumardi, ${ }^{30}$ bentuk Franchise sebagai format bisnis adalah seorang Penerima Waralaba memperoleh hak untuk memasarkan dan menjual produk atau pelayanan dalam suatu wilayah atau lokasi yang spesifik dengan menggunakan standar operasional dan pemasaran yang dari Pemberi Waralaba. Dalam hal ini, terdapat tiga jenis Franchise format bisnis, yaitu: Pertama, Franchise pekerjaan adalah bentuk Franchise dimana Penerima Waralaba yang menjalankan usaha waralaba pekerjaan sebenarnya membeli dukungan untuk usahanya sendiri. Misalnya, bisnis penjualan jasa penyetelan mobil dengan merek waralaba tertentu. Bentuk waralaba ini cenderung paling murah, umumnya membutuhkan modal yang kecil karena tidak menggunakan tempat dan perlengkapan yang berlebihan. Kedua, Franchise usaha yaitu waralaba usaha yang merupakan bidang waralaba yang paling berkembang pesat di Indonesia, bentuknya berupa toko eceran yang menyediakan barang atau jasa. Biaya yang dibutuhkan lebih besar dari waralaba pekerjaan karena dibutuhkan tempat usaha dan peralatan khusus. Ketika, Franchise Investasi merupakan waralaba usaha yang berskala besar, yang dilakukan oleh perusahaan yang sudah mapan, dan investasi awal yang dibutuhkan cukup besar. Misalnya, usaha hotel, maka dipilih cara kegiatan waralaba yang memungkinkan mereka memperoleh bimbingan dan dukungan.

Selain ketiga bentuk Franchise di atas, pada sekarang ini di Indonesia juga berkembang Franchise jenis baru yaitu group trading Franchise, yang menunjuk pada pemberian hak toko grosir maupun pengecer, seperti yang telah dilakukan oleh toko Seven

\footnotetext{
${ }^{30}$ Juajir Sumardi, Op.Cit., hlm. 22
} 
Eleven, Indo Maret maupun Econ Minimart. Bahkan sekarang disinyalir Indo Maret telah berkembang lebih dari 1.000 toko di seluruh Indonesia. Fakta ini tentu saja merupakan tanda bahwa usaha Franchise jenis ini sangat diminati oleh masyarakat dan dapat memberikan nilai positif bagi Usaha Kecil dan Menengah dalam mengembangkan dunia bisnis di Indonesia.

Adapun perjanjian bisnis dalam sistem Franchise merupakan pemberian hak oleh Pemberi Waralaba kepada Penerima Waralaba untuk menggunakan kekhasan usaha atau ciri pengenal bisnis di bidang perdangangan/jasa berupa jenis produk dan bentuk yang diusahakan termasuk identitas perusahaan. ${ }^{31}$ Perjanjian waralaba merupakan landasan legal yang berlaku sebagai undang-undang dalam mengoperasionalkan hubungan yang telah disepakati oleh Franchisee dan Franchisor, serta merupakan landasan untuk menjaga kepentingan Franchisor maupun Franchisee. ${ }^{32}$

Pada dasarnya Franchise adalah bentuk perjanjian yang isinya memberikan hak dan kewenangan khusus kepada pihak Franchisee, yang terwujud dalam bentuk hak untuk melakukan penjualan atas produk berupa barang dan atau jasa dengan mempergunakan nama dagang atau merek dagang tertentu dan hak untuk melaksanakan kegiatan usaha dengan atau berdasarkan pada suatu format bisnis yang telah ditentukan oleh Franchisor. ${ }^{33}$ Secara lebih detail, hak dan Kewajiban Antara Franchisor dengan Franchisee sebagai berikut: ${ }^{34}$

1. Hak dan kewajiban franchisor

Kewajiban dari franchisor adalah menyerahkan lisensi kepada franchisee, sedangkan yang menjadi hak dari franchisor adalah:

a. Logo merk dagang (trade-mark), nama dagang (trade name), dan nama baik (goodwill);

b. Format atau pola usaha;

c. Dalam kasus tertentu berupa rumus, resep, design, dan program khusus; serta

d. Hak cipta atas bagian dari hal diatas dalam bentuk tertulis dan terlindungi dalam bentuk undang-undang hak cipta.

2. Hak dan kewajiban franchisee Hak dari franchisee adalah menerima lisensi, sedang kewajibannya adalah membayar royalty kepada franchisor dan menjaga kualitas barang dan jasa yang di-franchise.

\footnotetext{
${ }^{31}$ Rooseno Hardjowidigdo, (1993), "Perspektif Pengaturan Perjanjian Franchise", Makalah Pertemuan Ilmiah tentang Usaha Franchise dalam Menunjang Pembangunan Ekonomi, Jakarta: BPHN, hlm. 5.

${ }^{32}$ Peni Rinda Listyawati, (2006), "Perjanjian Franchise sebagai Perjanjian Innomenaat dalam Pandangan Hukum Perdata", Jurnal Hukum Fakultas Hukum Universitas Islam Sultan Agung, Volume XVII, Nomor 22006, hlm. 188.

${ }^{33}$ Gunawawan Widjaja, Op.Cit., hlm. 47.

34 Nila Trisna, "Tinjauan Yuridis Terhadap Kedudukan Franchisee Dalam Perjanjian Franchise (Waralaba)", Jurnal Ius Civile, hlm. 18
} 
Adapun Franchise sebagai suatu perjanjian, Pasal 1320 KUH Perdata tetap mengikat sebagai syarat dasar dari sahnya perjanjian untuk waralaba yakni adanya: ${ }^{35}$

1. Kata sepakat dari mereka yang mengikatkan diri (Toestaming);

2. Kecakapan untuk mengadakan perikatan (Bekwaamheid);

3. Mengenai suatu obyek tertentu (Een Bepaal Onderwerp); dan

4. Mengenai kausa yang diperbolehkan (Geoorloofde Oorzaak).

Secara khusus mengenai syarat lainnya mengenai sahnya perjanjian waralaba diatur dalam Pasal 4 Peraturan Pemerintah Nomor 42 Tahun 2007, yakni bahwa waralaba diselenggarakan berdasarkan perjanjian tertulis antara Pemberi Waralaba dengan Penerima Waralaba dengan memperhatikan hukum Indonesia. Kemudian perjanjian tersebut apabila ditulis dalam bahasa asing maka harus diterjemahkan ke dalam bahasa Indonesia. Atas dasar pasal ini lah, maka syarat suatu perjanjian Franchise jika tidak ditulis dalam bahasa Indonesia maka perjanjian tersebut harus diterjemahkan dalam bahasa Indonesia.

\section{Pandangan Hukum Islam terhadap Royalti Penggunaan Merek dalam Sistem Franchise yang Diterapkan Di Indonesia}

Ketika kita membahas merek Franchise maka yang pertama kali yang harus kita pahami adalah tentang Hak Kekayaan Intelektual (HAKI) dari merek Franchise itu sendiri. Berdasarkan pasal 1 angka 1 Undang-Undang Nomor 28 Tahun 2014 tentang Hak Cipta menyatakan bahwa Hak Cipta adalah Hak Ekslusif pencipta yang timbul secara otomatis berdasarkan prinsip deklaratif setelah suatu ciptaan diwujudkan dalam bentuk nyata tanpa mengurangi atau pembatasan sesuai dengan ketentuan peraturan perundang-undangan. Kemudian Komisi Fatwa MUI menegaskan bahwa dalam hukum Islam, Hak Cipta dipandang sebagai salah satu huquq maliyyah (hak kekayaan) yang mendapat perlindungan hukum (mashun) sebagaimana mal (kekayaan), namun Hak Cipta yang mendapat perlindungan hukum Islam tersebut adalah hak cipta atas ciptaan yang tidak bertentangan dengan hukum Islam. ${ }^{36}$ Selanjutnya terkait dengan sistem bisnis, tentu kita juga harus memahami mengenai jual beli karena secara umum inti bisnis Franchise itu adalah jual beli baik itu produk maupun jasa. Oleh karena itu, sebelum membahas tentang sistem Franchise, terlebih dahulu penulis akan uraikan tentang hukum jual beli dalam hukum Islam. Pada dasarnya Jual beli mempunyai rukun dan syarat yang harus dipenuhi, sehingga jual beli itu dapat dikatakan sah

\footnotetext{
${ }^{35}$ M. Yahya Harahap, Segi-Segi Hukum Perjanjian, Bandung: PT.Alumni,1986, hlm. 32.

${ }^{36}$ Lihat Fatwa MUI Nomor 1 Tahun 2009 tentang Hak Cipta Ketentuan 1.
} 
oleh syara'. Syarat dalam jual beli adalah syarat yang disepakati oleh kedua pihak yang sedang melakukan akad jual beli. Ketentuan rukun jual beli adalah adanya Penjual, adanya pembeli, dilakukan dengan ijab-qabul, serta adanya benda atau barang yang diperjual belikan.

Dalam jual beli terdapat syarat-syarat yang harus dipenuhi sesuai dengan rukun jual beli di atas, yaitu:

1. Penjual dan Pembeli haruslah dewasa atau sadar, tidak dipaksa dengan cara yang tidak benar, maka tidak sah jual beli oleh orang yang dipaksa, dan beragama Islam. Selain itu, syarat penjual dan pembeli itu adalah kedua belak pihak tidak sedang bermusuhan.

2. Syarat Sighat jual beli yang diucapkan ketika transaksi jual beli dilakukan haruslah memenuhi unsur dibawah ini:

a. Berhadap-hadapan

b. Ditujukan kepada badan yang akad

c. Qabul (kalimat yang diucapkan oleh pembeli kepada penjual saat transaksi) diucapkan oleh orang yang dituju dalam $i j a \bar{b}$. Orang yang mengucapkan qabul haruslah orang yang diajak bertransaksi oleh yang mengucapkan ijāb, kecuali jika diwakilkan.

d. Ketika mengucapkan sigat harus disertai niat;

e. Harus menyebutkan barang atau jasa;

f. Pengucapan $i j a \bar{b}$ dan qabul harus sempurna;

g. Ijāb dan qabul tidak terpisah;

h. Antara $i j a \bar{b}$ dan qabul tidak terpisah dengan pernyataan lain;

i. Tidak berubah lafaz;

j. Bersesuaian antara $i j a \bar{b}$ dan qabul secara sempurna;

k. Tidak dikaitkan dengan sesuatu; dan

1. Tidak dikaitkan dengan waktu.

3. Syarat Barang yang dijual belikan harus memenuhi beberapa syarat, yaitu: Suci, maka tidak sah menjual barang najis atau barang yang haram sesuai ketentuan fiqih. Bermanfaat, artinya dapat dimanfaatkan secara syara', barang tersebut dapat diserahkan, barang yang dijualbelikan merupakan milik sendiri atau menjadi wakil orang lain. Terakhir adalah bahwa barang tersebut harus jelas dan diketahui oleh kedua orang yang melakukan akad, baik zat, ukuran maupun sifatnya.

Salah satu hal penting yang sering tidak terperhatikan oleh para pelaku jual beli adalah bahwa para ulama sepakat mengenai tidak bolehnya seseorang membuat akad jual beli yang 
disyaratkan di dalamnya pinjaman, atau sebaliknya tidak boleh meminjamkan sesuatu kepada orang lain dengan mensyaratkan adanya jual beli.

Islam memberikan alternatif kemitraan berupa pembiayaan tanpa riba dalam masalah keterbatasan modal bagi para pelaku usaha. Pembiayaan tanpa riba yang dimaksud salah satunya adalah syirkah. ${ }^{37}$ Terkait dengan kerjasama dalam juga beli ini, Fatwa Dewan Syariah Nasional Nomor 08/DSN-MUI/IV/2000 yang menentukan bahwa bahwa kebutuhan masyarakat untuk meningkatkan kesejahteraan dan usaha terkadang memerlukan dana dari pihak lain, antara lain melalui pembiayaan musyarakah yaitu pembiayaan berdasarkan akad kerjasama antara dua pihak atau lebih untuk suatu usaha tertentu, masing-masing pihak memberikan kontribusi dana dengan ketentuan bahwa keuntungan dan resiko akan ditanggung bersama sesuai dengan kesepakatan. ${ }^{38}$ Berdasarkan uraian tersebut, maka penulis menilai bahwa hukum sistem bisnis Franchise adalah mubah atau diperbolehkan, sepanjang memenuhi rukun dan syarat jual beli secara umum yang telah ditetapkan oleh syari'at.

Sistem Franchise juga dapat dipahami sebagai suatu perjanjian mengenai metode pendistribusian barang dan jasa kepada konsumen karena Franchisor dalam jangka waktu tertentu memberikan lisensi kepada Franchisee untuk melakukan usaha pendistribusian barang atau jasa di bawah nama identitas Franchisor dalam wilayah tertentu. Usaha tersebut harus dijalankan sesuai dengan prosedur dan cara yang ditetapkan oleh Franchisor. Franchisor memberikan bantuan terhadap Franchisee, sebagai imbalannya Franchisee membayar jumlah uang berupa initial fee dan royalty. Oleh karena itu adalah tepat apabila dalam regulasi di Indonesia mengatakan bahwa Franchise atau waralaba adalah hak khusus yang dimiliki oleh orang perseorangan atau badan usaha terhadap sistem bisnis dengan ciri khas usaha dalam rangka memasarkan barang dan/atau jasa yang telah terbukti berhasil dan dapat dimanfaatkan dan/atau digunakan oleh pihak lain berdasarkan perjanjian Franchise. ${ }^{39}$

Dilihat dari sudut bentuk perjanjian franchise, dapat dikemukakan bahwa perjanjian itu sebenarnya merupakan pengembangan dari bentuk kerjasama (syarikah). Hal ini disebabkan oleh karena dengan adanya perjanjian franchise itu, secara otomatis antara franchisor dengan franchisee terbentuk hubungan kerja sama untuk waktu tertentu (sesuai dengan perjanjian). Kerja sama tersebut dimaksud untuk memperoleh keuntungan bagi kedua

${ }^{37}$ Udin Saripudin, (2016), "Syirkah dan Aplikasinya dalam Lembaga Keuangan Syariah", Jurnal Ekonomi dan Bisnis, Volume 4, Nomor 1, April 2016, ISSN : 2503-4413, hlm. 64. Musyarakah.

${ }_{38}$ Lihat Fatwa Dewan Syariah Nasional Nomor 08/DSN-MUI/IV/2000 tentang Akad Pembiayaan

${ }^{39}$ Lihat Peraturan Pemerintah Nomor 42 Tahun 2007 tentang Waralaba. 
belah pihak. ${ }^{40}$ Dengan demikian dapat dilihat bahwa sistem bisnis Franchise apabila ditinjau dari hukum Islam maka akan dilihat serupa dengan musyarakah atau syirkah.

Adapun Syirkah itu sendiri mempunyai arti perserikatan. Elman Jauhari menjelaskan bahwa terhadap pengertian Syirkah ini, ulama fiqih beragam pendapat dalam mendefinisikan syirkah, antara lain: ${ }^{41}$ Menurut ulama malikiyah Syirkah merupakan Perkongsian adalah izin untuk mendayagunakan (tasharuf) harta yang dimiliki dua orang secara bersama sama oleh keduanya, namun masing masing memiliki hak untuk bertasharruf. Menurut Imam Hanabilah bahwa syirkah adalah Perhimpunan yang merupakan hak (kewenangan) atau pengolahan harta (tasharruf ) Adapun menurut Ulama Syafi'iyah syirkah adalah ketetapan pada sesuatu yang dimiliki dua orang atau lebih dengan cara yang masyhur (diketahui). Sedangkan Ulama Hanafiyah syirkah merupakan ungkapan tentang adanya transaksi (akad) antara dua orang yang bersekutu pada pokok harta dan keuntungan. Elman juga mengutarakan bahwa Syirkah menurut bahasa adalah ikhthilath (berbaur) atau percampuran, sedangkan menurut istilah syirkah (kongsi) ialah perserikatan yang terdiri atas dua orang atau lebih yang didorong. ${ }^{42}$

Adapun menurut Muhammad Syafi'i Antonio yang dikutip oleh Maratun Shalihah, Syirkah atau sering juga disebut syarikah adalah akad kerja sama antara dua pihak atau lebih untuk suatu usaha tertentu dimana masing-masing pihak memberikan kontribusi modal dengan kesepakatan bahwa keuntungan dan risiko akan ditanggung bersama sesuai dengan kesepakatan. ${ }^{43}$ Terkait rukun dan syarat syirkah, Moh. Faizal mengutarakan bahwa secara umum syirkah terdiri dari 3 (tiga) rukun, yaitu: Dua orang yang berakad (Al-Aqaidain), Siqat akad, serta obyek akad yakni harta dan pekerjaan. ${ }^{44}$ Sedangkan syarat sahnya syirkah tersebut meliputi syarat umum dan syarat khusus, sebagai berikut: ${ }^{45}$

1. Persyaratan umum, yaitu:

a) Dapat dipandang sebagai perwakilan;

b) Ada kejelasan dalam pembagian keuntungan; dan

c) Laba merupakan bagian umum dari jumlah diambil dari hasil laba harta perserikatan bahakan dari harta lain.

\footnotetext{
${ }^{40}$ Suryati Dzuluqy, (2019), “Bisnis Waralaba dalam Perspektif Hukum Ekonomi Syari'ah”, Jurnal Tahkim, Volume XV, Nomor 1, Juni 2019, hlm. 36.

${ }^{41}$ Elman Jauhari, (2019), "Implementasi Syirkah Dalam Perspektif Hukum Islam", Jurnal Hukum Sehasen, Volume 2, Nomor 2, November 2019, hlm. 4.

${ }^{42}$ Ibid., hlm. 4.

${ }^{43}$ Maratun Shalihah, (2016), "Konsep Syirkah dalam Waralaba", Jurnal Tahkim, Volume XII, Nomor 2, Desember 2016, hlm. 144

${ }^{44}$ Moh. Faizal, (2017), "Syirkah Prinsip Bagi Hasil pada Pembiayaan di Bank Syariah", Jurnal ISLAMIC BANKING, Volume 2, Nomor 2, Februari 2017, hlm. 70.

${ }^{45}$ Ibid., hlm. 70-71.
} 
2. Persyaratan khusus, yaitu:

a) Modal harus ada dan jelas, tidak boleh barang utang atau harta yang tidak ada di tempat, baik ketika akad maupun disaat jual beli.

b) Modal harus bernilai dan berharga secara mutlak, seperti uang oleh karena itu, tidak sah modal syirkah dengan barang-barang, baik yang bergerak maupun tetap.

Pada umumnya, syirkah secara garis besar dibagi menjadi 2 bentuk yaitu: Bentuk pertama adalah Syirkah amlâk (milik), yaitu persekutuan antara dua orang atau lebih untuk memiliki suatu benda. Bentuk kedua adalah Syirkah 'aqd, yaitu persekutuan antara dua orang atau lebih yang timbul dengan adanya perjanjian. ${ }^{46}$

Kemudian Syirkah 'aqd di atas dibagi menjadi lima (5), yaitu :

a. Syirkah amwâl, yaitu persekutuan antara dua orang atau lebih dalam modal/harta.

b. Syirkah a'mâl, yaitu perjanjian persekutuan antara dua orang atau lebih untuk menerima pekerjaan dari pihak ketiga yang akan dikerjakan bersama dengan ketentuan upah dibagi menjadi dua.

c. Syirkah wujûh, yaitu persekutuan antara dua orang atau lebih dengan modal harta dari pihak luar.

d. Syirkah Abdan, yaitu perserikatan dalam usaha atau bisnis dengan badan/tenaga mereka dalam sebuah bisnis dan mereka berbagi dari keuntungan yang di dapat.

e. Syirkah mudhârabah, yaitu kemitraan (persekutuan) antara tenaga dan harta, seorang (supplier) memberikan hartanya kepada pihak lain (pengelola) yang digunakan untuk bisnis, dengan ketentuan bahwa keuntungan (laba) yang diperoleh akan dibagi menurut kesepakatan kedua belah pihak. Dasarnya bentuk mudharabah adalah peminjaman uang untuk keperluan bisnis. Syirkah mudhârabah ini dibagi menjadi 2 bentuk, yaitu mudharabah muthlaqah dalam hal ini pemodal memberikan hartanya kepada pelaksana untuk dimudharabahkan dengan tidak menentukan jenis kerja, tempat dan waktu serta orang. Sedangkan mudharabah muqayyadah (terikat suatu syarat), adalah pemilik modal menentukan salah satu dari jenis di atas.

Dari penilaian tersebut, ada hal penting yang menjadi fokus penilaian, yaitu:

1. Pembelian Hak Kekayaan Intelektual (HAKI) berupa merek dagang, penemuan dan ciri khas produk atau menejemen usaha sebagai hak paten yang dimiliki Franchisor, sedangkan HAKI merupakan benda maknawi yang memiliki nilai jual.

\footnotetext{
${ }^{46}$ Sayyid sabiq, Fiqh al-Sunnah, terj. Kamaluddin Marzuki..., Op.cit., hlm.194-196.
} 
2. Konsep kerjasama pada Franchise ada kaitannya dengan Syirkah Aqd, yaitu kerjasama antara dua orang atau lebih dalam usaha untuk mendapatkan hasil yang dapat dinikmati bersama.

Terkait dengan HAKI di atas, maka dapat lihat bahwa pada praktiknya yang dilindungi oleh HAKI adalah kepentingan hak ekonomi dan hak moral seseorang atas karya kreatifitas mereka, baik dalam bentuk penemuan teknologi maupun karya cipta seni yang baru. Seorang penemu diberi hak monopoli berupa hak paten untuk melaksanakan sendiri penemuannya agar dalam waktu tertentu ia memperoleh manfaat ekonomi dari hasil kreatifitasnya. Seorang pencipta diberi kesempatan untuk memonopoli penggandaan dari karya ciptanya berupa copyright agar ia berkesempatan memperoleh manfaat ekonomi atas hasil kreatifitasnya. ${ }^{47}$ Kekayaan Intelektual merupakan hasil pemikiran karya manusia yang membutuhkan pengorbanan waktu, tenaga, dan biaya. Haki memiliki manfaat bagi pencipta dengan daya intelektualnya dalam menciptakan karya yang dilindungi misalnya pada bidang Hak Cipta. ${ }^{48}$

Pada Umumnya Hak Kekayaan Intelektual di bagi menjadi 2 yaitu Hak Kekayaan Industri dan Hak Cipta. Adapun juga Hak Kekayaan Industri di bagi menjadi 3 yaitu Hak Paten, Rahasia Dagang dan Hak Merek. ${ }^{49}$ Terhadap hal ini, Ulama menjelaskan beberapa hal yang berkenaan tentang hak maknawi ini, seperti pada karya ilmiyah, penemuan hasil riset, dan sebagainya merupakan hal yang boleh dijual dengan catatan bahwa Franchisee yang telah menerima lisensi harus mendapatkan pengarahan standarisasi mutu produk, agar konsumen tidak dirugikan karena mutu produk yang berbeda. Oleh Karena itu, brand name dan hal-hal lainnya dalam sistem bisnis Franchise ini sangat berkaitan erat dengan hak cipta (HAKI) Franchise itu sendiri.

Berdasarkan uraian di atas, maka dapat lebih meyakinkan kita bahwa Franchise itu sebenarnya adalah pengembangan dari bentuk kemitraan usaha dalam Islam yaitu syirkah. Berbeda dengan konsep mudharabah yang fokus pada sistem bagi hasil, sistem Franchise lebih dari itu, tidak hanya bicara masalah bagi hasil tetapi terdapat beberapa hal yang salah

${ }^{47}$ Indrasatya Octavianus Nasirun, (2014), "Kajian Hukum terhadap Perlindungan Royalti Atas Karya Cipta Lagu atau Musik dari Aspek UU No. 19 Tahun 2002”, Jurnal Lex et Societatis, Volume II, Nomor 9 , Desember 2014, hlm. 29.

${ }^{48}$ M. R. A. Pawitram, N. K. S. Dharmawan, dan A.K. S. Indrawati, 2017, "Pengaturan Lembaga Manajemen Kolektif berkaitan dengan Penarikan Royalti Berdasarkan Undang-Undang NO 28 Tahun 2014 Tentang Hak Cipta”, Jurnal Ilmiah Hukum Kertha Semaya, Volume 5, Nomor 1, hlm. 2.

${ }^{49}$ Jesi Andreanto dan Anak Agung Sri Utari, (2019), "Mekanisme Pembayaran Royalty Fee Berkaitan dengan Cover Lagu dalam Media Sosial”, Kertha Negara : Journal Ilmu Hukum, Volume 8, Nomor 1, Desember 2019, hlm. 3. 
satunya seperti merek dagang, sistem penjualan dan fee royalty penggunaan merek, dan lain sebagainya.

Adapun terhadap royalti atau fee royalti dalam penggunaan merek produk/usaha dalam kerjasama bisnis dengan sistem Franchise ini, maka tentu terlebih dahulu kita harus kembali melihat bagaimana konsep Franchise itu sendiri. Franchise merupakan suatu konsep kerjasama dalam menjalan suatu usaha atau bisnis yang mana kerjasama tersebut memiliki beberapa unsur dibawah ini, yaitu: Adanya perikatan, adanya hak pemanfaatan dan/atau penggunaan atas sebuah perusahaan, merek, sistem produksi, tata cara pengemasan, penyajian dan pengedarannya. Adanya subyek, yakni pihak Franchisor dan pihak Franchise. Adanya obyek, yakni hak atas kekayaan intelektual, penemuan baru maupun ciri khas usaha. Adanya imbalan, jasa atau sejumlah fee dan/atau royalty yang harus dibayarkan oleh pihak Franchise kepada pihak Franchisor. Sedangkan fee royalti merupakan biaya yang harus dibayar secara periodik atas penggunaan konsep, sistem, penemuan, proses, metode, logo, merek atau nama berdasarkan perjanjian Franchise, baik yang disertai dengan ikatan suatu jumlah minimum atau maksimum dari jumlah royalti tertentu atau tidak. Tujuan dikenakan fee royalti tersebut adalah agar suatu usaha dapat saling menguntungkan dan membantu demi kelangsungan usaha tersebut. ${ }^{50}$

Inti dari pembahasan bisnis Franchise di sini adalah tentang akad, yaitu akad antara Franchisor dengen Franchisee. Akad ini bersifat finansial yang menuntut adanya pertukaran imbalan karena Franchisor meminta fee atau royalti secara rutin dan periodik kepada Franchisee dengan imbalan penggunaan merek dagang tertentu, kontrol, dan asistensi. Hal yang paling mendasar pada penelitian ini adalah bahwa dalam sistem ini, Franchisee perlu membayar initial fee yang sifatnya sekali bayar, atau kadang sekali untuk satu periode tertentu, misalnya untuk lima tahun dan di atas itu biasanya Franchisee membayar royalti atau membayar sebagian dari hasil penjualan. Kadang Franchisee membayar dan perlu membeli bahan pokok atau peralatan (capital goods) dari Franchisor.

Konsep sistem syirkah pada dasarnya merupakan sebuah konsep yang secara tepat dapat memecahkan permasalahan permodalan. Satu sisi, prinsip Islam menyatakan bahwa segala setuatu yang dimanfaatkan oleh orang lain berhak memperoleh kompensasi yang saling

${ }^{50}$ Nurjannah MR dan Nazaruddin A Wahid, (2013), “Analisis Perhitungan Royalty Fee Franchise Menurut Konsep Musyarakah: Studi Pada Jarimatika Darussalam”, SHARE, Volume 2, Number 2, Juli December 2013, hlm 120. 
menguntungkan, baik terhadap barang modal, tenaga atau barang sewa. ${ }^{51}$ Di sisi lain Islam menolak dengan tegas kompensasi atas barang modal berupa bunga, namun dalam konsep Franchise tidak mengenal adanya bunga. Fee royalty yang dibebankan oleh Franchisor kepada Franchisee dalam perjanjian Franchise bukanlah bunga melainkan lebih pada kompensasi dan bagi hasil atas sistem Franchise yang dipergunakan oleh Franchisee. Sebenarnya Islam telah memubahkan akad Syirkah dan menjadikan penghasilan yang didapatkan darinya adalah penghasilan yang halal. Umar bin Al-Khattab pernah berbisnis dengan Akad Syirkah Mudharabah. Rasulullah Shallallahu 'Alaihi Wasallam sendiri pernah berakad Syirkah Mudharabah dengan Khadijah sebelum menjadi istrinya dan mengizinkan sistem bisnis tersebut setelah beliau diangkat menjadi Rasul. Para sahabat juga banyak yang berbisnis dengan akad Syirkah. Ibnu Al-Mundzir mengatakan bahwa kebolehan akad Syirkah Mudharabah sudah menjadi Ijma Shahabat. Secara ringkas kita dapat mengatakan bahwa fee ataupun royalty yang dibebankan oleh franchisor kepada Franchisee merupakan bagian dari kesatuan sistem bisnis Franchise sehingga hukum royalty tersebut dinisbahkan kepada hukum sistem bisnis Franchise itu sendiri yaitu mubah atau diperbolehkan.

Dalam sistem Franchise format bisnis ini yang banyak dipergunakan oleh masyarakat Indonesia, terdapat permasalahan yang kerap menjadi polemik, yaitu:

1. Franchisee telah membayar uang sewa hak intelektual dan berbagai layanan yang diberikan oleh Franchisor. Dengan demikian, seharusnya ia tidak lagi memungut bagi hasil bulanan dari keuntungan pihak Franchisee. Adanya pungutan fee bulanan ini, menjadikan nominal nilai sewa hak-hak intelektualnya tidak jelas, atau yang disebut dengan gharar. Dan Anda telah mengetahui bahwa adanya gharar (ketidak-jelasan) pada suatu akad menjadikannya terlarang dalam syariat.

Abu Hurairah radhiallahu 'anhu mengisahkan:

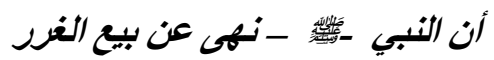

Artinya bahwasanya Nabi shallallahu 'alaihi wa sallam melarang jual-beli yang bersifat untung-untungan (gharar) (HR. Muslim). Hadist ini, walaupun secara khusus berbicara tentang hukum jual beli, namun larangan ini berlaku pula pada akad-akad komersial lainnya seperti bisnis Franchise.

51 Chapra dalam Deny Setiawan, (2013), “Kerja Sama (Syirkah) dalam Ekonomi Islam”, Jurnal Ekonomi, Volume 21, Nomor 3, September 2013, hlm. 1. 
2. Lain dari permasalahan di atas, ternyata fee yang diambil Franchisor dihitung dari keuntungan kotor, bukan dari keuntungan bersih. Ketentuan ini sudah barang tentu sangat membebani pihak Franchisee.

Terhadap dua permasalahan tersebut, penulis akan memaparkan benang merah terhadap permasalahan tersebut yaitu dengan melakukan salah satu dari opsi-opsi sebagai berikut: Opsi pertama yaitu menerapkan akad serikat dagang. Dengan opsi ini, pihak Franchisor yang bermodalkan hak kekayaan intelektualnya (baca: merk dagang), bersinergi dengan pihak Franchisee yang bermodalkan dana. Sebagai konsekuensinya, kedua pihak membuat kesepakatan dalam penentuan nilai sewa hak kekayaan intelektual atau merk dagang) selama batas waktu tertentu. Dengan demikian komposisi modal masing-masing jelas, sebagaimana hak dan kewajiban keduanya-pun telah jelas. Selanjutnya setiap keuntungan yang didapatkan, dibagi ke masing-masing pihak berdasarkan kesepakatan. Opsi Kedua yaitu opsi sewa hak kekayaan intelektual. Pada opsi ini, pihak Franchisor memungut uang sewa atas penggunaan hak kekayaan intelektualnya yang berupa merek dagang, dan lainnya, selama batas waktu yang disepakati pula. Namun sebagai konsekuensi opsi ini, Franchisor tidak berhak mendapatkan fee dari keuntungan usaha. Dengan menerapkan satu dari kedua opsi ini, maka kedua permasalahan yang dipersoalkan di atas dapat dihindarkan, sehingga dapat memenuhi ketentuan syariat dalam serikat usaha atau sewa-menyewa.

Pada prinsipnya, opsi manapun yang dipilih, maka pada tahapan aplikasinya, pihak Franchisor harus benar-benar mentransfer semua sistem, teknologi, dan manajemen usaha yang berlaku. Ketentuan ini bertujuan agar akad Franchise tidak menipu konsumen, sehingga merek dagang yang disewakan kepada pihak Franchisee bukan sekedar nama kosong. Merek dagang yang selama ini mewakili sistem kerja, teknologi pengolahan dan mutu barang atau layanan, benar-benar didapat oleh konsumen, sehingga tidak ada unsur penipuan.

Sekarang kita perlu kembali kepada pembahasan tentang kaidah-kaidah hukum Islam terutama permasalahan muamalah yang salah satunya adalah syirkah atau kerjasama/kemitraan usaha. Dalam hukum Islam, dalam pembahasan kaidah-kaidah fiqih dikatakan bahwa pada prinsipnya hukum mu'amalah adalah boleh selama tidak ada dalil yang mengharamkannya (al-ashlu fil mu'amalat al-Ibadah illa an yadulladalilun a' tahrimihi). Adapun dalil yang dapat mengubah hukum mu'amalah dari boleh kepada haram tersebut harus mengacu kepada dalil exsplisit (Sharih) dari Al-Qur'an dan hadist Nabi Shallallahu 'Alaihi Wasallam, atau dalil lain melalui uji verifikasi tertentu seperti ijma' (konsensus para 
Ulama), qiyas (analogi), mashalih mursalah (konsep mashlahat) dan lain-lain. Pada prinsipnya sistem nilai yang terdapat hukum Islam (syari'at) sebagai filter moral bisnis bertujuan untuk menghindari berbagai penyimpangan dan menjauhi pantangan.

Untuk menghindari terjadinya penyimpangan tersebut, sistem bisnis Franchise harus bebas dari beberapa pantangan dalam hal jual beli ataupun kemitraan usaha, yaitu: ${ }^{52}$

a. Maysir yaitu segala bentuk spekulasi judi yang mematikan sektor riil dan tidak produktif

b. Asusila yaitu praktek usaha melanggar kesusilaan dan norma sosial

c. Gharar yaitu segala transaksi yang tidak transparan dan tidak jelas sehingga berpotensi merugikan salah satu pihak.

d. Haram yaitu objek transaksi dan proyek usaha yang diharamkan syari'ah;

e. Riba yaitu segala bentuk distorsi mata uang yang menjadi komoditas dengan menggunakan tambahan (bunga) pada transaksi kredit atau pinjaman dan pertukaran/barter lebih antar barang ribawi sejenis. Pelarangan riba ini mendorong usaha yang berbasis kemitraan yang saling menguntungkan dan kenormalan (sunatullah) bisnis, disamping menghindari praktek pemerasan, eksploitasi, dan penzaliman oleh pihak yang memiliki posisi tawar tinggi terhadap pihak yang berposisi tawar rendah;

f. Ihtikar yaitu penimbunan monopoli barang dan jasa untuk tujuan permainan harga;

g. Berbahaya yaitu segala bentuk transaksi dan usaha yang membahayakan individu maupun masyarakat serta bertentangan dengan maslahat dengan maqashidusy syari'ah.

Berdasarkan uraian tersebut diatas, hukum royalty fee penggunaan merek dalam sistem bisnis Franchise adalah mubah. Ketentuan hukum ini dapat menjadi tidak jelas, subhat bahkan dapat menjadi haram apabila royalty tersebut merupakan hasil dari penjualan dari setiap produk barang/jasa dari franchisee yang notabenenya kurang lebih mirip dengan bunga dari penjualan produk sedangkan harga barang/produk/jasa sudah dibayar oleh Franchisee sesuai dengan kesepakatan, tapi yang jelas bahwa fee royalti seperti itu menzholimi franchisee sedangkan dalam konsep syirkah tidak dibenarkan adanya ketidakadilan terhadap salah satu pihak dalam perikatan tersebut. Teori istinbath hukum seperti ini merupakan penerapan dari kaidah "Tahrim lil 'Aridh".

Apabila kesepakatan atau perjanjian Franchise tersebut memuat hal fee royalti yang tidak sesuai dengan hukum Islam, maka tidak hanya terkait royalti itu sendiri yang diharamkan tetapi juga perjanjian itupun sifatnya haram untuk dilaksanakan. Menurut penulis, dalam perjanjian franchise tersebut, fee royalti yang dikenakan kepada Franchisee oleh

\footnotetext{
${ }^{52}$ Dalil-dalil tentang ketujuh poin di atas didasarkan pada Qs: 5:3,90, Qs:2: 278-279.
} 
Franchisor harus merupakan harga sewa atas brandname ataupun penggunaan sistem Franchise tersebut oleh franchisee, bukan royalti keuntungan dari hasil penjualan produk, sehingga dengan demikian mengharuskan kenaikan fee royalti bukan karena kenaikan hasil penjualan produk atau jasa, melainkan kenaikan harga sewa periodik atas sistem Franchise yang digunakan berdasarkan kesepakatan atau perjanjian kedua belah pihak. Dengan demikian, maka hal yang mengikuti dari sistem ini adalah bahwa akad Franchise harus dengan multiakad, yaitu akad syirkah dan akad sewa-menyewa (ijarah). Pada dasarnya, pembahasan Syirkah sekarang ini merupakan sebagai bentuk respon terhadap praktik dan kebutuhan industri dalam menjalankan syariah sebagai sistem bisnis, syirkah dikembangkan dengan teknik-teknik yang dimodifikasi agar berdaya saing secara bisnis serta tetap berada dalam koridor syariah. ${ }^{53}$

Selain itu, sistem Franchise ini tidak dibenarkan untuk melakukan tujuh ataupun salah satu dari pantangan dalam kemitraan usaha yang telah disebutkan di atas. Oleh karena itu, ketujuh pantangan yang disebut tersebut haruslah dihindari dalam pelaksanaan kerjasama bisnis Franchise. Secara prinsip, kaidah kerjasama dalam hukum Islam termasuk kerjasama bisnis hendaklah selalu dalam kerangka kebaikan dan ketakwaan, bukan dalam kerangka dosa dan kejahatan.

\section{PENUTUP}

\section{Kesimpulan}

Berdasarkan uraian diatas dapat simpulkan bahwa sistem Franchise yang diterapkan di Indonesia adalah sistem franchise format bisnis, dimana seorang Franchisee memperoleh hak untuk memasarkan dan menjual produk atau pelayanan dalam suatu wilayah atau lokasi yang spesifik dengan menggunakan standar operasional dan pemasaran dari Franchisor. Sistem ini terdari dari tiga jenis, yaitu: Franchise pekerjaan, Franchise usaha dan Franchise Investasi. Adapun hukum fee royalti penggunaan merek dalam sistem bisnis Franchise adalah mubah atau diperbolehkan mengingat bahwa sistem bisnis franchise ini sendiri diperbolehkan karena dianalogikan sebagai syirkah sepanjang memenuhi syarat dan rukun syirkah tersebut. Namun, hukum fee royalti tersebut dapat berubah menjadi haram apabila bisnis yang dilakukan mengandung unsur riba atau hal-hal yang dilarang oleh syari'at Islam.

${ }^{53}$ Miti Yarmunida, (2018), "Eksistensi Syirkah Kontemporer”, Jurnal Ilmiah Mizani: Wacana Hukum, Ekonomi, dan Keagamaan, Volume 1, Nomor 2, 2018, Hlm. 520. 


\section{Buku}

\section{DAFTAR PUSTAKA}

Basarah, Moch, dan H.M. Faiz Mufidin, (2008), Bisnis Franchise dan Aspek-Aspek Hukumnya, Bandung: PT. Citra Aditya Bakti.

Bunging, Burhan, (2007), Metodologi penelitian kualitatif: Aktualisasi Metodologi ke Arah Ragam Varian Kontemporer, Jakarta: PT. RajaGrafindo Persada.

Fox, Stephen, (1993), Membeli dan Menjual Bisnis dan Franchise, Jakarta: Elex Media Konputindo.

Harahap, M. Yahya, (1986), Segi-Segi Hukum Perjanjian, Bandung: PT.Alumni.

Karamoy, Amir, (2013), Percaturan Waralaba Indonesia, Jakarta: PT Foresight Asia.

Khaerandy, Ridhwan, (1992), Aspek-Aspek Hukum Franchise, Yogyakarta: Majalah Unisa.

Mendelsohn, Martin, (1986), The Guide to Franchising, England: Oxford.

Muhammad, Abdulkadir, (2004), Hukum Perusahaan Indonesia, Bandung: Citra Aditya Bakti.

Salim HS., (2008), Perkembangan Hukum Kontrak Innominat di Indonesia, Jakarta: Sinar Grafika.

Soekanto, Soerjono dan Sri Mamudji, (2006), Penelitian Hukum Normatif Tinjauan Singkat, Jakarta: Rajawali Pers.

Sumardi, Juajir, (1995), Aspek-aspek hukum perusahaan tradisional dan Franchise, Bandung: Citra Aditya Bakti.

Sutendi, Adrian, (2008), Hukum Waralaba, Bogor: Ghalia Indonesia.

UNCTC, (1987), Transnational Corporation and Technology Transfer: Effects and Policy Issues, United Nations, New York: UNCTC.

Webster, Bryce, (1986), The Insider's Guide to Franchising, AMACON.

Widjaja, Gunawan, (2003), Waralaba, Jakarta: PT. RajaGrafindo Persada.

\section{Peraturan Perundang-Undangan}

Undang-Undang Nomor 15 Tahun 2001 tentang Merek.

Peraturan Pemerintah Nomor 42 Tahun 2007 tentang Waralaba.

Keputusan Menteri Perindustrian dan Perdagangan Nomor 259/MPP/KEP/7/1977 tentang Ketentuan dan Tata Cara Pelaksanaan Pendaftaran Waralaba. 
Fatwa Dewan Syariah Nasional Nomor 08/DSN-MUI/IV/2000 tentang akad pembiayaan Musyarakah.

Fatwa MUI Nomor 1 Tahun 2009 tentang Hak Cipta.

\section{Jurnal}

Andreanto, Jesi, dan Anak Agung Sri Utari, (2019), "Mekanisme Pembayaran Royalty Fee Berkaitan dengan Cover Lagu dalam Media Sosial”, Kertha Negara: Journal Ilmu Hukum, Volume 8, Nomor 1, Desember 2019.

Darmawan, Walid, (2010), "Analisis Sistem Penetapan Franchise Fee dan Royalty Fee Pada Franchise BRC”, Jurnal Al-Iqtishad: Volume II, Nomor 1, Januari 2010.

Dewi, Putu Eka Trisna, (2015), "Implementasi Ketentuan Restrukturisasi Kredit terhadap Debitur Wanprestasi pada Kredit Perbankan", Jurnal Magister Hukum Udayana, Volume 4, Nomor 2.

Dzuluqy, Suryati, (2019), "Bisnis Waralaba dalam Perspektif Hukum Ekonomi Syari'ah", Jurnal Tahkim, Volume XV, Nomor 1, Juni 2019.

Faizal, Moh., (2017), "Syirkah Prinsip Bagi Hasil pada Pembiayaan di Bank Syariah”, Jurnal Islamic Banking, Volume 2 Nomor 2 Februari 2017.

Hardjowidigdo, Rooseno, (1993), "Perspektif Pengaturan Perjanjian Franchise", Makalah Pertemuan Ilmiah tentang Usaha Franchise dalam Menunjang Pembangunan Ekonomi, Jakarta: BPHN.

Hudiarini, Sri, dkk. (2018), "Waralaba Model Bisnis Baru yang Berkelanjutan Ditinjau dari Aspek Hukum", Jurnal Panorama Hukum, Volume 3, Nomor 1, Juni 2018 ISSN: 2527-6654.

Jauhari, Elman, (2019), “Implementasi Syirkah Dalam Perspektif Hukum Islam”, Jurnal Hukum Sehasen, Volume 2, Nomor 2, November 2019.

Katrinasari, Bella, (2017), “Tinjauan Hukum Terhadap Wanprestasi Royalty Rahasia Dagang Dalam Perjanjian Waralaba”, Privat Law, Volume V, Nomor 1, Januari-Juni 2017.

Listyawati, Peni Rinda, (2006), "Perjanjian Franchise sebagai Perjanjian Innomenaat dalam Pandangan Hukum Perdata", Jurnal Hukum, Fakultas Hukum Universitas Islam Sultan Agung Volume XVII, Nomor 2, 2006.

MR., Nurjannah dan Nazaruddin A Wahid, (2013), “Analisis Perhitungan Royalty Fee Franchise Menurut Konsep Musyarakah: Studi Pada Jarimatika Darussalam”, SHARE, Volume 2, Nomor 2, Juli-Desember 2013.

Nasirun, Indrasatya Octavianus, (2014), "Kajian Hukum terhadap Perlindungan Royalti Atas Karya Cipta Lagu atau Musik dari Aspek UU No. 19 Tahun 2002”, Jurnal Lex et Societatis, Volume II, Nomor 9, Desember 2014. 
Pawitram, M. R. A., N. K. S. Dharmawan, dan A.K. S. Indrawati, (2017), "Pengaturan Lembaga Manajemen Kolektif berkaitan dengan Penarikan Royalti Berdasarkan Undang-Undang NO 28 Tahun 2014 Tentang Hak Cipta”, Jurnal Ilmiah Hukum Kertha Semaya, Volume 5, Nomor 1.

Saripudin, Udin, (2016), "Syirkah dan Aplikasinya dalam Lembaga Keuangan Syariah", Jurnal Ekonomi dan Bisnis, Volume 4, Nomor 1, April 2016, ISSN: 2503-4413.

Setiawan, Deny, (2013), "Kerja Sama (Syirkah) dalam Ekonomi Islam”, Jurnal Ekonomi, Volume 21 Nomor 3 September 2013.

Shalihah, Maratun, (2016), "Konsep Syirkah dalam Waralaba”, Jurnal Tahkim, Volume XII, Nomor 2, Desember 2016.

Slamet, Sri Redjeki, (2015), "Waralaba (Franchise) di Indonesia", Jurnal Lex Jurnalica, Volume 8 Nomor 2, April 2011.

Sulaeman, Dede, (2019), "Keuntungan yang Didapat dari Mengembangkan Usaha dengan Sistem Franchise (Studi Kasus di Indonesia)", Jurnal JDM, Volume 2, Nomor 01, April 2019.

Trisna, Nila, "Tinjauan Yuridis Terhadap Kedudukan Franchisee Dalam Perjanjian Franchise (Waralaba)", Jurnal Ius Civile.

Wibowo, Eko, (2007), "Faktor-faktor yang Mempengaruhi Pertumbuhan Jaringan Waralaba (Studi Kasus pada Yayasan Soroban Mental Aritmatika Indonesia Semarang)", Jurnal Sains Pemasaran Indonesia, Volume VI, Nomor 1, Mei 2007.

Yarmunida, Miti, (2018), “Eksistensi Syirkah Kontemporer”, Jurnal Ilmiah Mizani: Wacana Hukum, Ekonomi, dan Keagamaan, Volume 1, Nomor 2, 2018.

\section{Internet}

Kusumayanti, Made Martarina, dkk. "Implementasi Perlindungan Hukum bagi Franchisor dalam Perjanjian Waralaba (Pada Edam Burger di Denpasar)”, Artikel, Fakultas Hukum Universitas Udayana, hlm. 5-6. Sumber: https://ojs.unud.ac.id/index.php/kerthasemaya/article/view/43775, diakses tanggal 20 Juni 2020. 